\title{
Stored product psocids (Psocoptera): External morphology of eggs
}

\author{
ZUZANA KUČEROVÁ
}

Research Institute of Crop Production, Department of Stored-Product Pest Control, Drnovská 507, 16106 Prague 6, Czech Republic; e-mail: kucerova@hb.vurv.cz

Key words. Psocoptera, Liposcelis, Lepinotus, Trogium, Dorypteryx, Psyllipsocus, Lachesilla, egg measurements, chorion surface structure, scanning electron micrographs, keys

\begin{abstract}
Eggs of thirteen synanthrophic psocids of the families Trogiidae, Psyllipsocidae, Liposcelididae and Lachesillidae, commonly occurring in stored products in Europe, are described. Descriptions are based on overall appearance during embryogenesis, size and surface sculpturing. Morphological details are illustrated using scanning electron micrographs. A key for distinguishing eggs at both the generic and species level is provided. The presence or absence of a micropyle and aeropyle is discussed.
\end{abstract}

\section{INTRODUCTION}

This paper presents a study of the external morphology of eggs of the synanthropic psocids commonly occurring in Europe. It is a part of a larger project on the comparative morphology of the eggs of stored-product arthropods aimed at facilitating their identification (Kučerová \& Stejskal, 2002). Psocid eggs or their shells are often found in grain and other foods, stuck to the surface of the substrate, even when other developmental stages are absent (e.g. after sieving).

Observations on psocid eggs were summarised by Seeger (1979), New (1987) and Lienhard (1998). However, the eggs of most species are still unknown. Little or no SEM-based information is available on the external morphology of the chorion surface.

The aim of this study was to provide data for the identification of eggs and to improve the general knowledge of psocid eggs. A key for the identification of the eggs of stored product psocids at the generic and species level is presented.

\section{MATERIAL AND METHODS}

Adult psocids were identified using Lienhard (1998) and the taxonomic arrangement and nomenclature of the species follows this author.

Eggs of the following species of psocid: Trogium pulsatorium (L.), Lepinotus patruelis Pearman, Lepinotus reticulatus Enderlein, Lepinotus inquilinus von Heyden, Dorypteryx domestica (Smithers), Psyllipsocus ramburii Sélys-Longchamps, Liposcelis decolor (Pearman), Liposcelis corrodens (Heymons), Liposcelis bostrychophila Badonnel, Liposcelis brunnea Motschulsky, Liposcelis entomophila (Enderlein), Liposcelis paeta Pearman, Lachesilla pedicularia (L.) were collected from special laboratory breeding stocks reared in darkness at $25^{\circ} \mathrm{C}$ and 75 relative humidity and fed a mixture of powdered wheat germ, yeast and oat flakes. About 50 females were allowed to oviposit for 1-3 days in glass containers ( $4 \mathrm{~cm}$ deep with a $3 \mathrm{~cm}$ inner diameter) containing very little food and then removed. The eggs were collected gently with a brush, wetted with a drop of distilled water and subsequently air-dried. They were then examined under light and electron microscopes, measured, or their overall appearance during embryogenesis described.
Measurements were made under a light microscope using a micrometer. A minimum of 30 eggs were measured for each species (only 10 in the case of $P$. ramburii).

Fresh eggs without any previous fixation were placed on special stubs covered with double-sided sticky tape and coated with platinum in Sputter Coater SDC 050 (thickness of platinum layer was $4 \mathrm{~nm}$ ). They were then studied under a JEOL JSM 6400 scanning electron microscope (SEM) at magnifications of $180 \times-20.000 \times$. Approximately 30 eggs were examined under the SEM. Surface sculpture and thickness of the egg shell were measured directly from micrographs.

\section{MORPHOLOGICAL RESULTS}

The eggs of stored product psocids are laid naked but may be subsequently covered with faecal material or with pieces of the substrate. According to Cobben (1968) the dorsum of a mature embryo abuts again the dorsal side of an egg. In all psocid species studied here the position of the embryo in the egg is the same. As described by Seeger, 1979 (p. 37) the venter of an embryo lies uppermost in an egg and its head is oriented towards the anterior end, thus eggs are usually attached to the substratum by their dorsal side.

Egg dimensions are recorded in Table 1. Observations on egg morphology are summarised in the key to genera, and the descriptions of the individual genera are complemented with keys to species. The chorion structures described are obvious when viewed under a stereomicroscope or light microscope (mainly macrostructuresdepressions, projections) and a SEM (microstructuresgranulation, micropapillae, micropylar and aeropylar area).

\section{KEY TO GENERA OF THE EGGS OF THE MOST COMMON STORED-PRODUCT PSOCIDS OCCURRING IN EUROPE}

1 Egg ovoid (Fig. 6a,7a,b) $\ldots \ldots \ldots \ldots \ldots \ldots \ldots \ldots 2$

- Egg of other shape $\ldots \ldots \ldots \ldots \ldots \ldots \ldots \ldots \ldots . . . \ldots$

2 Egg width $<200 \mu \mathrm{m}$, anterior end distinctly narrower than posterior, LW ratio $>1.5(1.7-2.2)$ (Fig. 7a,b) . . . . . . . Liposcelis 
- Egg width $>200 \mu \mathrm{m}$, anterior end only slightly narrower than posterior, LW ratio $<1.5$ (1.4) (Fig. 6a) . . . . . . . .

Psyllipsocus

3 Egg with both ends drawn out into a point (Fig. 1a, 2a) . 4

- Egg ellipsoid (Fig. 5a) or slightly rectangular (Fig. 13a) . 5

4 Egg with $\mathrm{L} / \mathrm{W}$ ratio $>2$ (Fig. 1a) $\ldots \ldots \ldots \ldots$ Trogium

- Egg with $\mathrm{L} / \mathrm{W}$ ratio $<2$ (Fig. 4a) $\ldots \ldots \ldots \ldots$ Lepinotus

5 Egg regularly ellipsoid with both ends rounded (Fig. 5a). Chorion covered with club-shaped projections (micropapillae, height about $2 \mu \mathrm{m}$ visible under an optical microscope) (Fig. 5b) . . ................. Dorypteryx

- Egg slightly rectangular, upper surface flattened (Fig. 8a) Chorion covered with semiglobular tubercles (height about $0.5 \mu \mathrm{m}$ not visible under an optical microscope) (Fig. 8c) .

........................... Lachesilla

\section{Suborder Trogiomorpha}

\section{Trogiidae}

Genus Trogium Illiger (T. pulsatorium, Figs 1a-h)

Size and overall appearance. The eggs of $T$. pulsatorium, the type species and the only important storage pest in this genus, are oblong with the upper (ventral) surface flat or slightly convex and the bottom (dorsal) surface distinctly convex. Both ends are pointed, but the anterior end is more tapered (Fig. 1a). The average egg size is $0.51 \times$ $0.22 \mathrm{~mm}$ (L/W ratio 2.4 ). Freshly laid eggs are generally white in colour, slightly glossy and opalescent. The chorion has a distinct macrostructure that is visible under a stereomicroscope. This structure is formed by hexagonal depressions (Fig. 1b). These depressions (about 30-40 $\mu \mathrm{m}$ in diameter) uniformly cover almost all the surface of the egg and probably are imprints of the follicular cells (Fig. 1c). As the embryo develops, the egg becomes matt in colour, and the rusty pigment of the large eyes together with the light ochre spot of the mouthparts and the black spot of the egg-burster become visible at the anterior end. The thickness of the egg shell after hatching is about $0.28-0.36 \mu \mathrm{m}$ (Fig. 1e).

Surface sculpturing. The chorion has distinct microstructures in addition to the above mentioned macrostructure. The surface is covered with irregular rounded tubercles (height about $1 \mu \mathrm{m}$, width $1.1 \mu \mathrm{m}$ ), which vary in size, shape and density (Fig. 1b-d).

Other typical structures are two types of opening at the ends of an egg. One type are probably micropyles: the oval openings $(1.58 \mu \mathrm{m})$ situated on a smooth area without tubercles. These openings lead into ducts indicated on the surface (Fig. 1f, g). The number of openings varies, averaging $11(5-13)$. They are mostly situated on the upper (ventral) surface at the posterior end, but sometimes also on the anterior end or on both ends. The second type of opening consists of a deep narrow irregular crack-like hole (1-2 $\mu \mathrm{m}$ in diameter) on a smooth area, without any tubercular structures (Fig. 1h) (probably a respiratory area). The shape and the number of cracks is variable, averaging $10(6-19)$. The area with
TABLE 1. Egg measurements of some synanthropic species of Psocoptera (mean \pm SD in $\mu \mathrm{m})$.

(* = measurements cited by Kučerová \& Jokeš, 2002)

\begin{tabular}{|c|c|c|c|c|}
\hline Species & $\mathrm{n}$ & Length (L) & Width (W) & Ratio $\mathrm{L} / \mathrm{W}$ \\
\hline \multicolumn{5}{|l|}{ TROGIOMORPHA } \\
\hline \multicolumn{5}{|l|}{ TrogiIDaE } \\
\hline $\begin{array}{l}\text { Trogium } \\
\text { pulsatorium }\end{array}$ & 30 & $512.9 \pm 40.1$ & $220.2 \pm 18.9$ & $2.35 \pm 0.205$ \\
\hline $\begin{array}{l}\text { Lepinotus } \\
\text { patruelis }\end{array}$ & 30 & $461.0 \pm 14.2$ & $258.7 \pm 11.5$ & $1.78 \pm 0.07$ \\
\hline $\begin{array}{l}\text { Lepinotus } \\
\text { reticulatus }\end{array}$ & 30 & $372.1 \pm 13.3$ & $217.0 \pm 9.67$ & $1.72 \pm 0.09$ \\
\hline $\begin{array}{l}\text { Lepinotus } \\
\text { inquilinus }\end{array}$ & 30 & $416.2 \pm 8.44$ & $222.2 \pm 8.47$ & $1.88 \pm 0.07$ \\
\hline \multicolumn{5}{|l|}{ PSYLLIPSOCIDAE } \\
\hline $\begin{array}{l}\text { Dorypteryx } \\
\text { domestica* }\end{array}$ & 76 & $375.5 \pm 1.57$ & $240.4 \pm 1.36$ & $1.56 \pm 0.01$ \\
\hline $\begin{array}{l}\text { Psyllipsocus } \\
\text { ramburii }\end{array}$ & 10 & $357.6 \pm 9.66$ & $253.3 \pm 7.11$ & $1.41 \pm 0.05$ \\
\hline \multicolumn{5}{|l|}{ TROCTOMORPHA } \\
\hline \multicolumn{5}{|l|}{ LIPOSCELIDIDAE } \\
\hline $\begin{array}{l}\text { Liposcelis } \\
\text { decolor }\end{array}$ & 30 & $368.5 \pm 12.3$ & $173.9 \pm 7.70$ & $2.12 \pm 0.12$ \\
\hline $\begin{array}{l}\text { Liposcelis } \\
\text { corrodens }\end{array}$ & 30 & $345.7 \pm 8.64$ & $178.1 \pm 5.79$ & $1.94 \pm 0.09$ \\
\hline $\begin{array}{l}\text { Liposcelis } \\
\text { bostrychopila }\end{array}$ & 30 & $328.6 \pm 8.65$ & $188.1 \pm 5.74$ & $1.75 \pm 0.06$ \\
\hline $\begin{array}{l}\text { Liposcelis } \\
\text { brunnea }\end{array}$ & 30 & $370.8 \pm 9.62$ & $178.6 \pm 5.19$ & $2.08 \pm 0.07$ \\
\hline $\begin{array}{l}\text { Liposcelis } \\
\text { entomophila }\end{array}$ & 30 & $379.9 \pm 7.44$ & $175.2 \pm 6.92$ & $2.17 \pm 0.09$ \\
\hline $\begin{array}{l}\text { Liposcelis } \\
\text { paeta }\end{array}$ & 30 & $352.8 \pm 10.0$ & $197.5 \pm 9.00$ & $1.79 \pm 0.08$ \\
\hline \multicolumn{5}{|l|}{ PSOCOMORPHA } \\
\hline $\begin{array}{l}\text { LACHESILLIDAE } \\
\text { Lachesilla }\end{array}$ & & & & \\
\hline pedicularia & 30 & $339.0 \pm 4.90$ & $194.5 \pm 7.33$ & $1.75 \pm 0.07$ \\
\hline
\end{tabular}

the cracks is usually situated on the upper (ventral) surface at both ends of an egg, sometimes only at one end. If both types of openings are present on the same end, the crack area is situated peripheral to the micropyles.

\section{Genus Lepinotus von Heyden}

Size and overall appearance. The eggs of Lepinotus are analogous to those of Trogium in their general shape, but are shorter and more bulky (L/W ratio 1.7-1.8) (Fig. 2a). Their average size is $0.37-0.46 \times 0.22-0.26 \mathrm{~mm}$, depending on the species (Table 1). Freshly laid eggs are white in colour, slightly glossy and opalescent. The whole surface has a distinct permanent macrostructure. The chorion is covered with longitudinal rows of wrinkled hollows. This pitting is probably again an imprint of the follicular cells. This pattern is species dependent. In $L$. inquilinus, the type species of the genus (Fig. 2b) and in

Fig. 1. Trogium pulsatorium. $\mathrm{a}-$ entire egg (upper $=$ ventral view, anterior end at left); $\mathrm{b}$ - hexagonal depressions in the middle of the ventral surface; $c$ - imprints of follicular cells at anterior end; $d$ - detail of the lateral tubercles at the anterior end; $e$ - egg shell after hatching; $\mathrm{f}$ - micropylar area at the posterior end; $\mathrm{g}$ - detail of micropyle openings; $\mathrm{h}$ - respiratory area at the anterior end. 


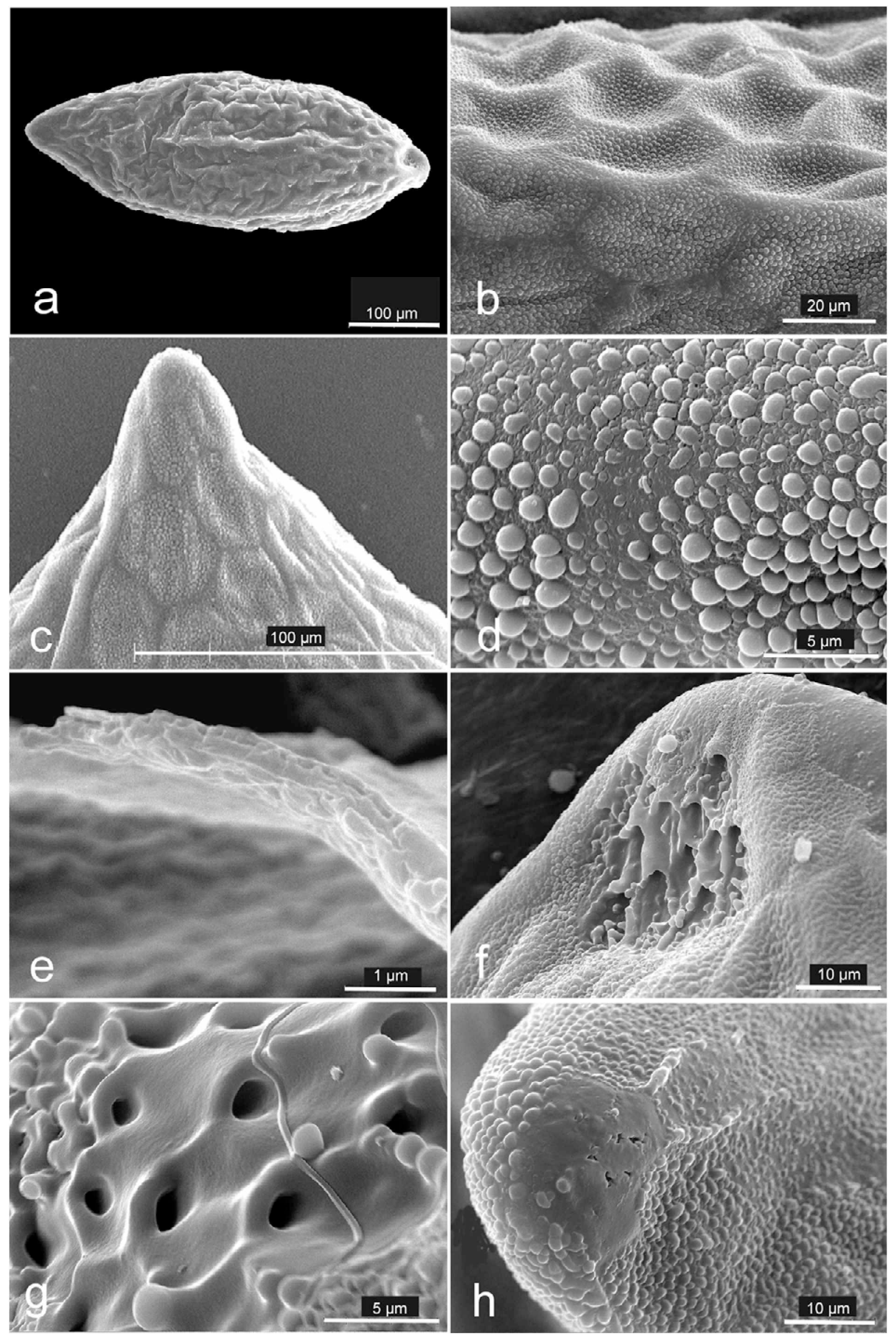


L. patruelis (Fig. 3a) the longitudinal rows are interrupted on the upper surface at the anterior end by a pattern of transverse folds. These transverse folds are absent in $L$. reticulatus (Fig. 4a). As the embryo develops, the eggs become a matt white in colour and the black pigment of the large eyes, the black spot of the egg-burster and the light ochre spot of the mouthparts become visible through the chorion at the anterior end. The egg shell is about $0.35 \mu \mathrm{m}$ thick (L. patruelis) (Fig. 3d).

Surface sculpturing. SEM micrographs revealed a distinct microstructure. The surface bears more or less elongated projections (micropapillae) (nearly circular in cross-section) that vary in size (height $0.9-4.5 \mu \mathrm{m}$, diameter $0.3-0.9 \mu \mathrm{m}$ ) and density according to their location on an egg, and the species (Fig. 2c-f, 3b-d, 4b).

Lepinotus species also have two types of openings at each end of an egg. The smooth area with the regular oval openings (micropyle area) is situated on the upper surface of the posterior end and has a similar structure to that of Trogium eggs. The average number of openings varies with species ( $L$. reticulatus -3, L. patruelis $-5.5, L$. inquilimus -13) (Fig. 2g-h, 3e, 4d). The inner diameter of the micropylar opening is about $1.6 \mu \mathrm{m}$ ( $L$. inquilinus). The second type, the irregular crack-like openings on the smooth area without micropapillae (respiratory area) usually occur on the dorsal surface at the anterior end ( $L$. inquilinus) or at both the anterior and posterior ends ( $L$. patruelis, L. reticulatus) (Fig. 3f, 4e,f). The shape, size $(0.3-1.4 \mu \mathrm{m})$ and number of cracks (usually more than 10 $-30)$ vary between and within species.

\section{KEY TO EGGS OF LEPINOTUS SPECIES}

1 Egg length $>0.4 \mathrm{~mm}$, upper (= ventral) surface of anterior end with transverse folds (Fig. 2b, 3a) . . . . . . . . . 2

- Egg length $<0.4 \mathrm{~mm}$, upper surface of anterior end without transverse folds (Fig. 4a).

Upper (ventral) surface of egg with one type of micropapillae (length $0.89 \times 0.27 \mu \mathrm{m}$ ) (Fig. 4b), regularly covering ridges and bottoms of hollows. Posterior end with micropapillae. Dorsal surface of egg bare (Fig. $4 c) \quad \ldots \ldots \ldots \ldots \ldots \ldots$. reticulatus

2 Number of micropyles $>10$, projections on top of anterior end elongated, regularly shaped, length $>3 \mu \mathrm{m}(3.6 \times 0.9$ $\mu \mathrm{m}$ ) (Fig. 2e), average number of transverse folds 13.5 $(10-17)$.

Transverse folds with smaller micropapillae $(1.2 \times 0.45 \mu \mathrm{m})$ (Fig. $2 \mathrm{c}$.), otherwise upper (= ventral) surface covered with longer micropapillae $(2.2-4.5 \times 0.9 \mu \mathrm{m})$ concentrated mainly on ridges of longitudinal rows (Fig. 2d). Posterior end and dorsal surface of egg with

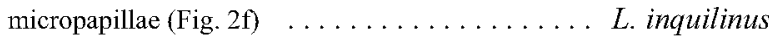

- Number of micropyles $<10$, projections on top of anterior end short, irregularly shaped, their length $<3 \mu \mathrm{m}(1.4 \mu \mathrm{m})$ (Fig. 3b), on average of 8 (7-9) transverse folds Size of micropapillae on transverse folds $1.1-1.7 \mu \mathrm{m} \times 0.7-0.8 \mu \mathrm{m}$. (Fig. 3c). Posterior end and dorsal surface of egg bare (Fig. 3f) ...

L. patruelis

\section{Psyllipsocidae}

Genus Dorypteryx Aaron (D. domestica, Fig. 5a-f)
This genus is represented by one species in this study, which is not the type species of the genus. Measurements and general description given by Kučerová \& Jokeš (2002) are updated.

Size and overall appearance. The egg is ellipsoidal in shape and symmetrical, on average $0.37 \mathrm{~mm}$ long and $0.24 \mathrm{~mm}$ wide at its broadest point. Both ends are almost of the same shape, regularly rounded (Fig. 5a). The eggs are white in colour. The freshly laid eggs are glossy, smooth and pellucid. During embryogenesis the surface becomes a matt white, and the "macrostructure" consists of a wrinkling of the egg chorion. In the last period of development the colour turns to yellowish and ochre yellow (especially at the anterior end). The red pigment of the eyes and the mouthparts of a developing embryo can be seen through the egg shell at the anterior end. The egg shell (measured without projections) is about 0.36 $\mu \mathrm{m}$ thick (Fig. 5c).

Surface sculpturing. The chorion appears smooth, but a distinct microstructure is visible under high magnification. The entire surface is finely granulated and also more or less evenly covered with club or upright projections (micropapillae $1.9 \times 1.0 \mu \mathrm{m}$ ) including both ends (Fig. $5 b)$. The micropyle area is situated on the ventral surface at the posterior end and consists of about 12 (10-14) wide "half-funnels". Every half-funnel leads into a separate duct, which is visible on the surface. Some funnels are flattened, with no visible opening, others have one or two openings (Fig. 5d-f). The total or partial flattening of the funnels was possibly caused by placing the specimens in a vacuum during processing for SEM. The diameter of the openings is about $3.0 \mu \mathrm{m}$, and width of the halffunnel about $12.0 \mu \mathrm{m}$. No aeropyles were found.

Genus Psyllipsocus Sélys-Longchamps (P. ramburii, Fig. $6 \mathrm{a}-\mathrm{f}$ )

$P$. ramburii is the type species of the genus and the only species occurring in Europe.

Size and overall appearance. The egg is regularly ovoid. Its average size is $0.35 \times 0.25 \mathrm{~mm}$. The anterior end is slightly narrower than the posterior end, which has a moderate depression (Fig. 6a). The chorion has a distinct macrostructure (visible under a stereomicroscope). The macrostructure is formed by round bulges (average $13.8 \mu \mathrm{m}$ ) (Fig. 6b, e), which are regularly spread over the whole surface of the chorion. The bulges are probably imprints of the follicular cells and may become wrinkled radially or their top indented in the course of time. The eggs are generally white in colour without any opalescence. Freshly laid eggs are glossy. During embryogenesis the surface becomes a matt white. In the last period of development the red pigment of the eyes and the weakly ochre mouthparts of a developing embryo can be seen through the egg shell at the anterior end. The egg

Fig. 2. Lepinotus inquilinus. a - entire egg (lateral view, anterior end at left); $\mathrm{b}-$ entire egg (upper $=$ ventral view, anterior end at left); $\mathrm{c}$ - detail of transverse folds with smaller micropapillae; $\mathrm{d}$ - ridges of longitudinal rows with longer micropapillae; e - top of anterior end; $f$ - posterior end; $g$ - posterior end with micropyles; $h$ - detail of micropyle. 

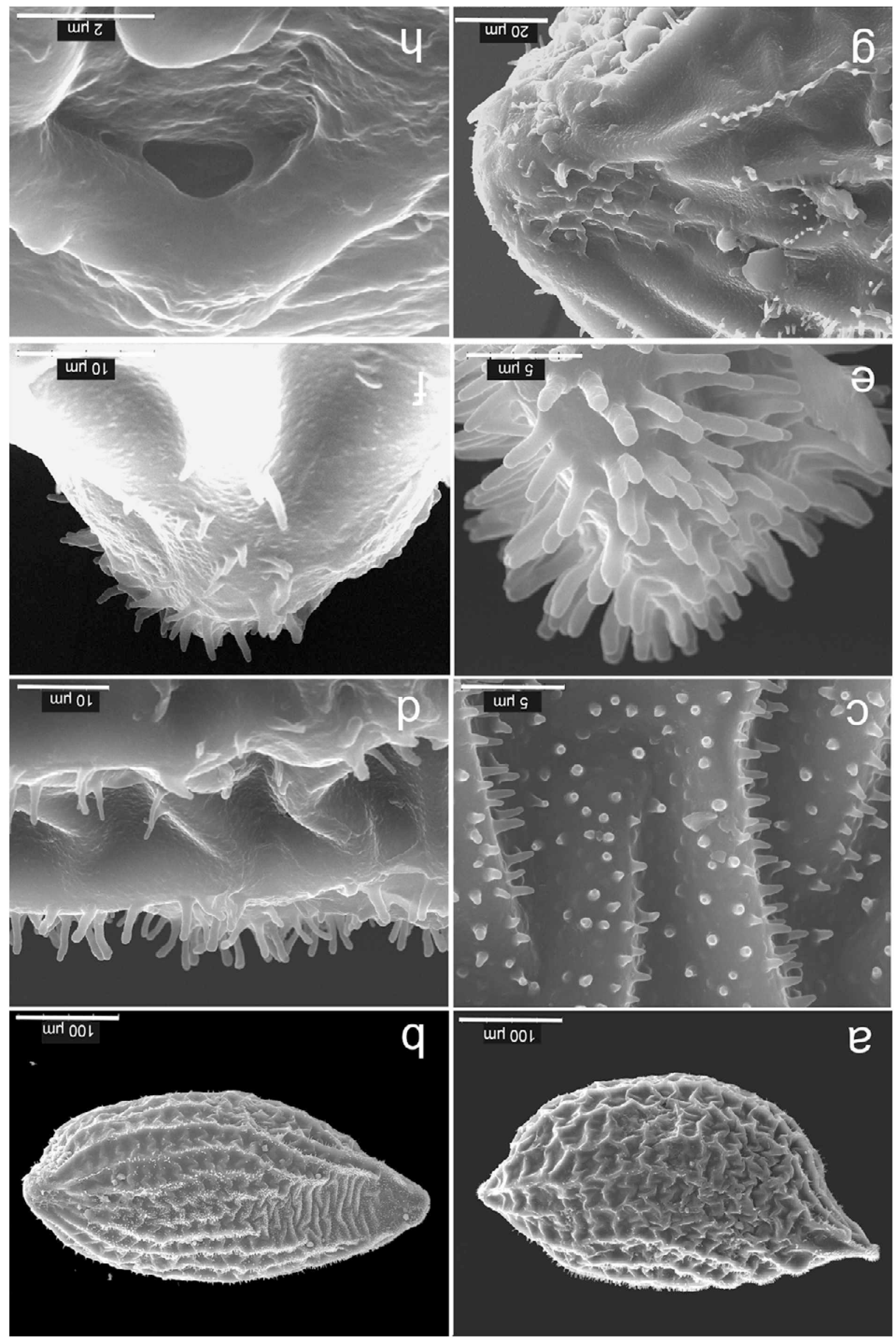

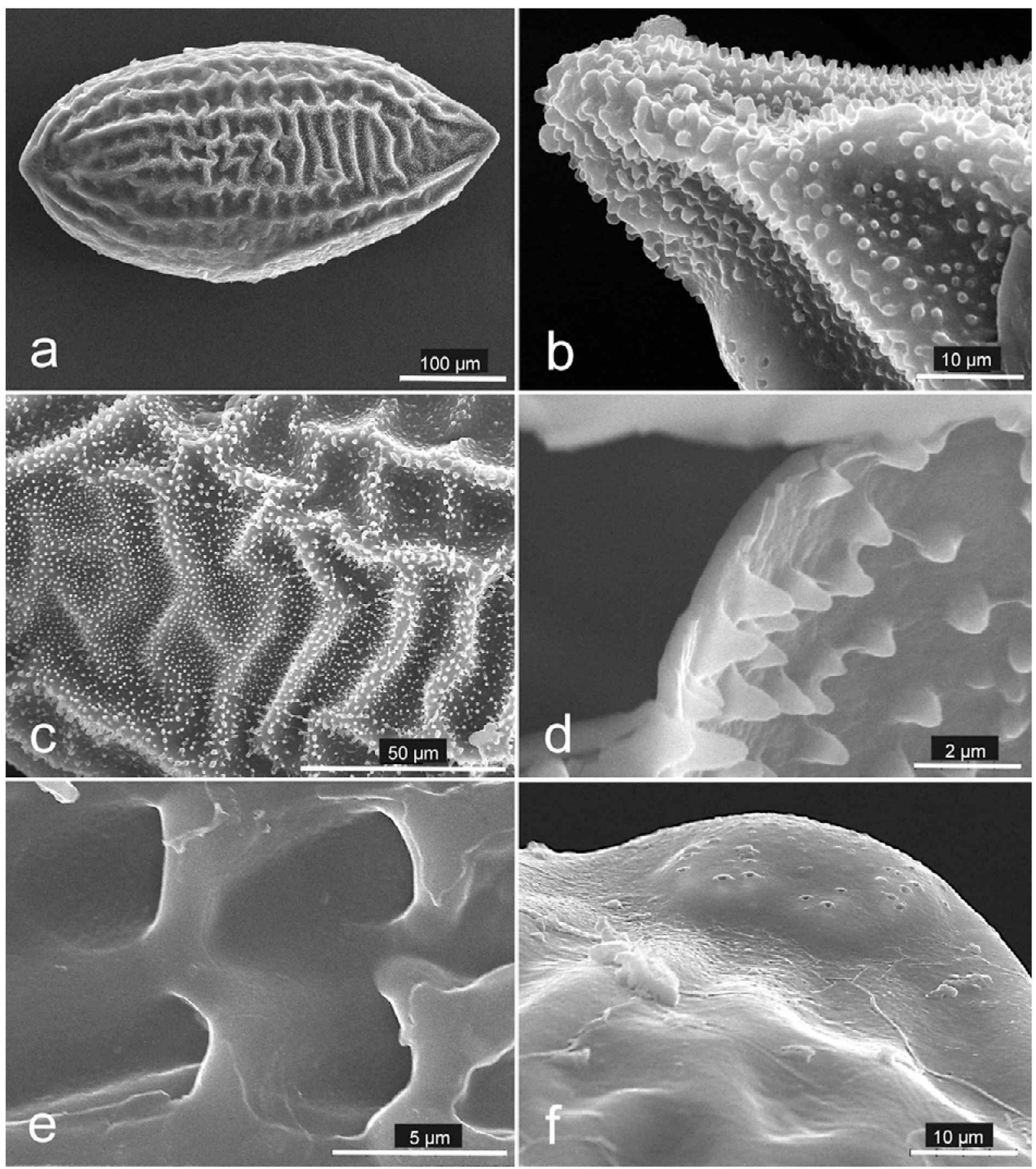

Fig. 3. Lepinotus patruelis. $\mathrm{a}-$ entire egg (upper $=$ ventral view, anterior end at right); $\mathrm{b}-$ anterior end; $\mathrm{c}-$ transverse folds (ventral surface); $\mathrm{d}$ - egg shell after hatching; e - micropyles (posterior end); $\mathrm{f}$ - respiratory area (posterior end).

shell is about $0.25 \mu \mathrm{m}$ thick (with micropapillae about 0.5 $\mu \mathrm{m})$ (Fig. 6d).

Surface sculpturing. The entire surface is granulated with short micropapillae $(0.27 \times 0.28 \mu \mathrm{m})($ Fig. $6 \mathrm{~b}-\mathrm{d}, \mathrm{f})$, which are larger $(0.6 \mu \mathrm{m}$ in diameter) and denser on the crests of ridges (Fig. $6 \mathrm{c}$ ) and at both ends. The micropylar area is situated at the posterior end in a small longitudinal depression and consists of about 4 (2-10) openings. The inner diameter, at the entrance of the opening, is about 5.1 (2.5-7) $\mu \mathrm{m}$ (Fig. 6f). No aeropyles were found.

\section{Suborder Troctomorpha}

\section{Liposcelididae}

Genus Liposcelis Motschulsky (Figs 7a-h).

Type species of the genus is L. brunnea.

Size and overall appearance. The average size is $0.33-0.38 \times 0.17-0.20 \mathrm{~mm}$ depending on the species (Table 1). The eggs are ovoid with the anterior end more pointed and the posterior one regularly rounded. They are generally white in colour. Freshly laid eggs are glossy and smooth (Fig. 7a). During the development of the embryo, the eggs lose their gloss and the surface becomes 

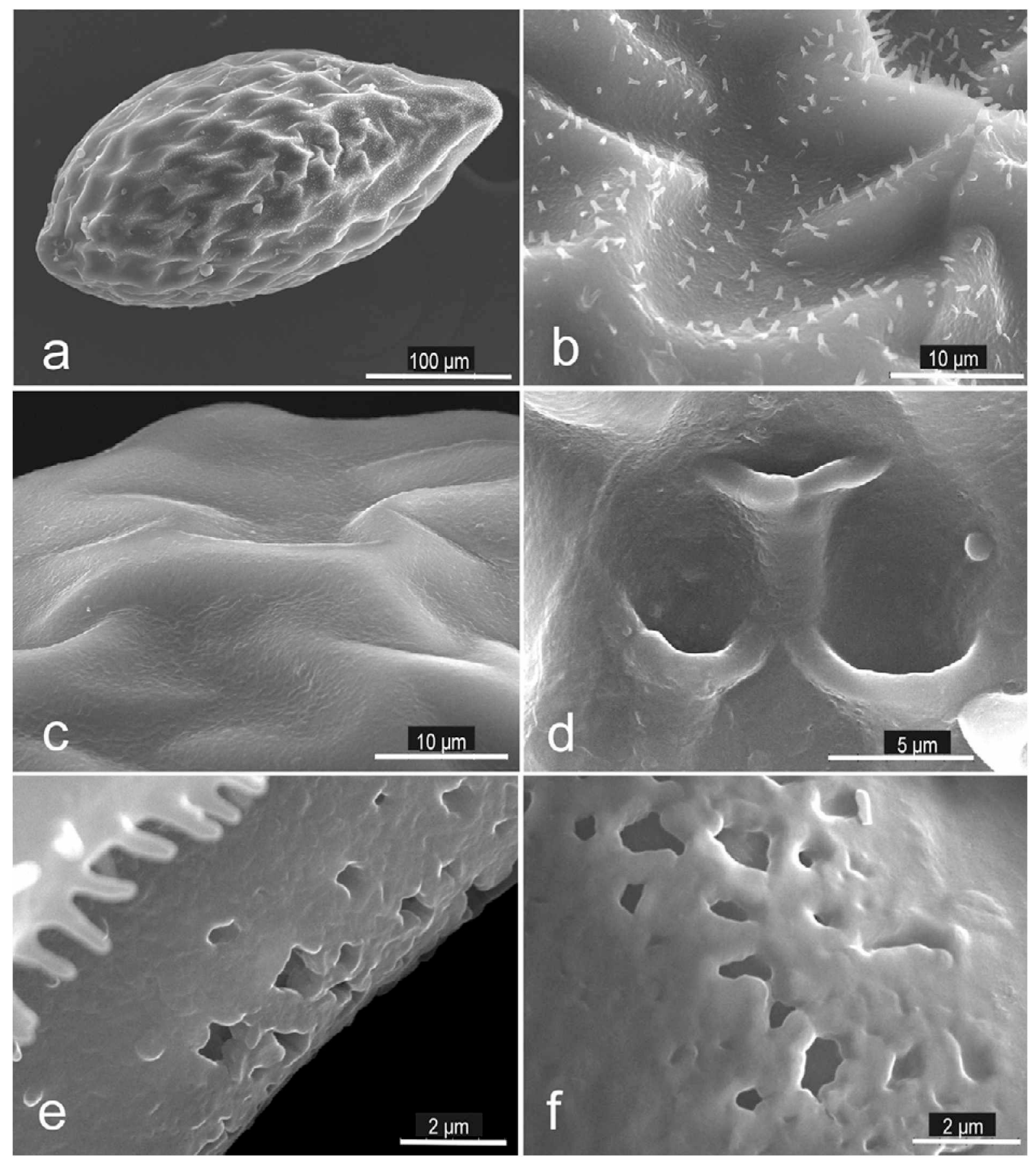

Fig. 4. Lepinotus reticulatus. a - entire egg (upper $=$ ventral view, anterior end at right); $\mathrm{b}-$ micropapillae (on ventral surface); $\mathrm{c}-$ bottom of the egg (= dorsal surface); $\mathrm{d}$ - micropyles (posterior end); e - respiratory area (lateral view of anterior end); $\mathrm{f}-$ respiratory area (posterior end).

slightly wrinkled (Fig. 7b). The colour of eggs close to hatching tends towards ochre-yellow. The dark reddishblack eyespots and the ochre spot of the mouthparts (mandibles and cibarial sclerite) are visible through the chorion at the anterior end. The thickness of the egg shell (L. decolor - chorion with granulation structure) is about $0.42 \mu \mathrm{m}$ (Fig. 7e).

Surface sculpturing. The chorion looks smooth, but SEM (magnification $2000 \times$ and more) reveals a soft granulation over the entire surface, the size of which depends on the species (Fig. 7c, d). At the posterior end on the ventral surface of the egg there is a micropylar region made up of interlacing ridges (Fig $7 \mathrm{f}-\mathrm{h}$ ). The posteriorly diverted micropylar openings (inner diameter 1.2 $\mu \mathrm{m}, L$. corrodens, $L$. decolor) are situated at the apex of each ridge (Fig. 7h). The number of ridges varies (about $4-12$ ). Sometimes some of the ridges are only poorly defined (Fig. 7f). No other type of opening was found in the surface of the chorion. 


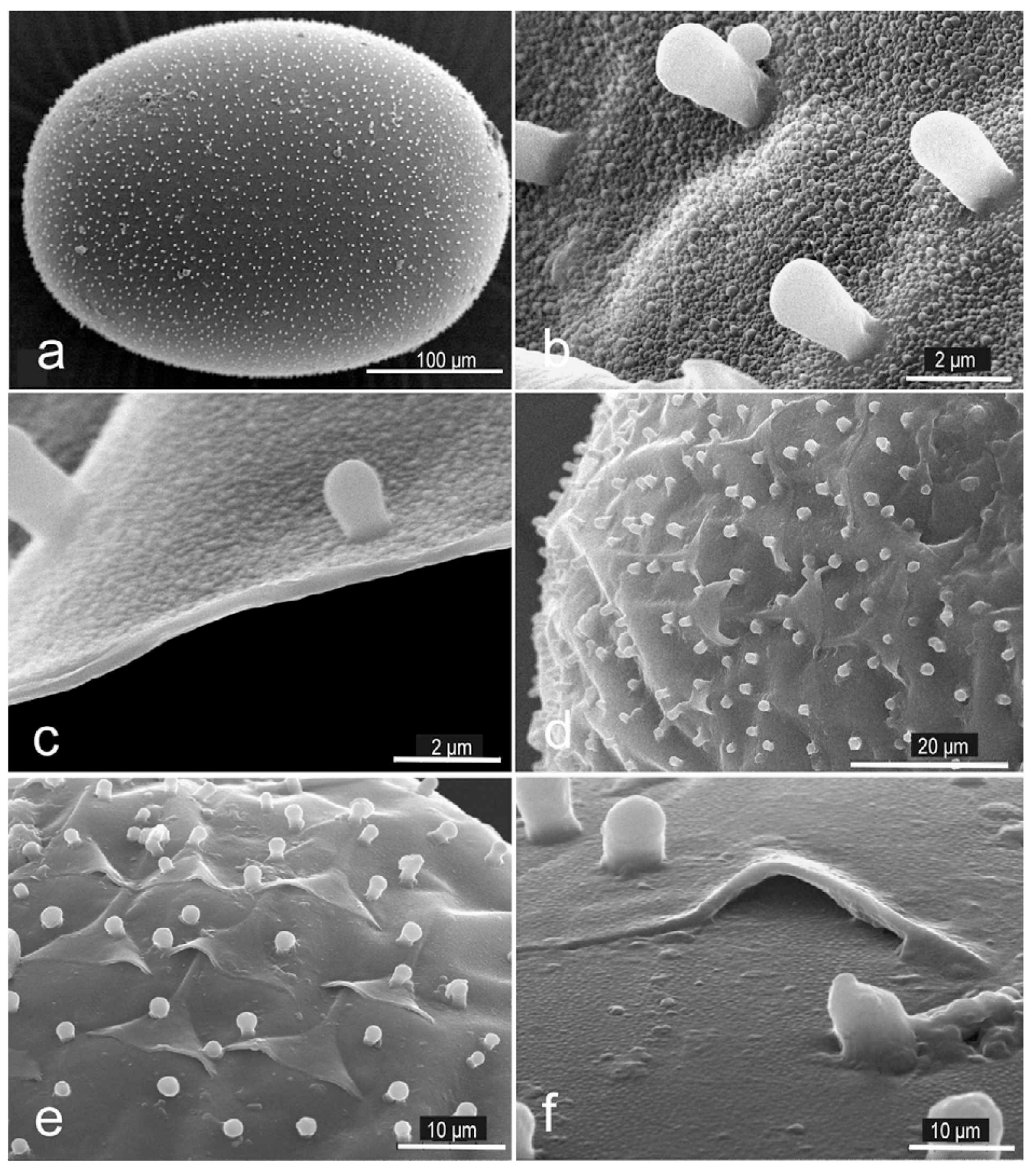

Fig. 5. Dorypteryx domestica a - entire egg (upper = ventral view, anterior end at right); $\mathrm{b}-$ granulation and micropapillae; $\mathrm{c}-$ egg shell after hatching; $d$ - micropylar area (posterior end); $\mathrm{e}$ - detail of the micropylar area; $\mathrm{f}$ - micropylar opening.

The Liposcelis eggs included in this study can be placed in one of two species groups depending on their general shape $(\mathrm{L} / \mathrm{W}$ ratio). The size of the microstructural granulation on the chorion varies between species and also depends on the position on the egg.

\section{KEY TO EGGS OF LIPOSCELIS SPECIES}

1 Ratio $\mathrm{L} / \mathrm{W}<2$ (Fig. $7 \mathrm{a}) \quad \ldots \ldots \ldots \ldots \ldots \ldots \ldots \ldots \ldots \ldots \ldots \ldots \ldots \ldots \ldots \ldots$

- Ratio L/W $>2$ (Fig. 7b) $\ldots \ldots \ldots \ldots \ldots \ldots \ldots$

2 Size of granulation on middle part of egg $<0.2 \mu \mathrm{m}(0.15$ $\mu \mathrm{m})($ Fig. $7 \mathrm{c}) \ldots \ldots \ldots \ldots \ldots \ldots \ldots \ldots$. . . . . . . . . . . . . . .
- Size of granulation on middle part of egg $>0.2 \mu \mathrm{m}$ (Fig. $7 \mathrm{~d})$

3 Area inside micropylar ridges smooth (Fig. 7g)

L. bostrychophila

- Area inside micropylar ridges granulated as on rest of chorion (Fig. $7 \mathrm{~h}) . \ldots \ldots \ldots \ldots \ldots \ldots \ldots$. . . . . . . . . . . . . . . .

4 Size of granulation on middle part of egg $<0.18 \mu \mathrm{m}(0.16)$

L. brunnea

Size of granulation on the middle part of egg $>0.18 \mu \mathrm{m} \quad 5$

5 Size of lateral granulation at anterior end of egg $<0.27 \mu \mathrm{m}$ $(0.25 \mu \mathrm{m})$, average number of micropylar ridges $10(5-11)$

L. decolor 

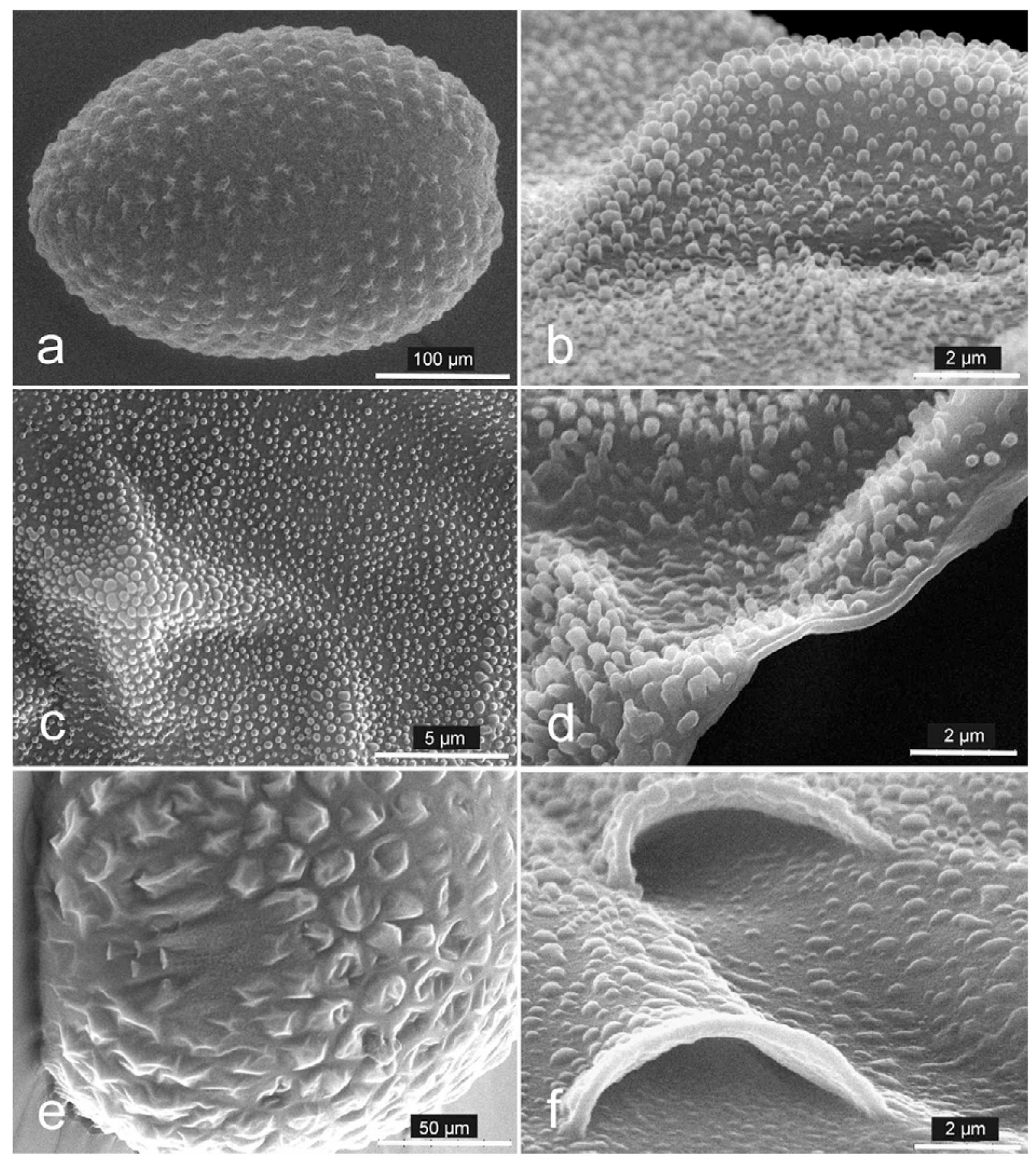

Fig. 6. Psyllipsocus ramburii. a - entire egg, (upper = ventral view, anterior end at left); $\mathrm{b}$ - bulge (anterior end); $\mathrm{c}-$ micropapillae on the top of ridge; $d$ - egg shell after hatching; $\mathrm{e}-$ micropylar area (posterior end); $\mathrm{f}$ - detail of micropyle opening.

- Size of lateral granulation at anterior end of egg $>0.27 \mu \mathrm{m}$ $(0.33 \mu \mathrm{m})$, average number of micropylar ridges $5(3-8) \quad$.

\section{Suborder Psocomorpha}

\section{Lachesillidae}

Genus Lachesilla Westwood (L. pedicularia, Fig. 8a-h)

Size and overall appearance. The eggs of $L$. pedicularia, the type species of the genus, are ventrally (= upper surface) slightly flattened with moderately angular ends (Fig. 8a). Their average size is $0.34 \times 0.19 \mathrm{~mm}$. Freshly laid eggs are white in colour, slightly glossy and opalescent. On the upper (= ventral) surface there are usually longitudinal tortuous corrugations. As the embryo develops, the eggs become dark ochre-grey and become more iridescent. The eyes of an embryo are not visible through the upper surface.

Surface sculpturing. The SEM micrograph (Fig. 8d) of the egg shell revealed a two-layered chorion (total thickness of about $0.8-1.2 \mu \mathrm{m}$ ). The inner layer is made up of three-lamellae $(0.49 \mu \mathrm{m})$. The outer layer ("extrachorion", $0.4 \mu \mathrm{m}$ ), which covers the upper and lateral egg 

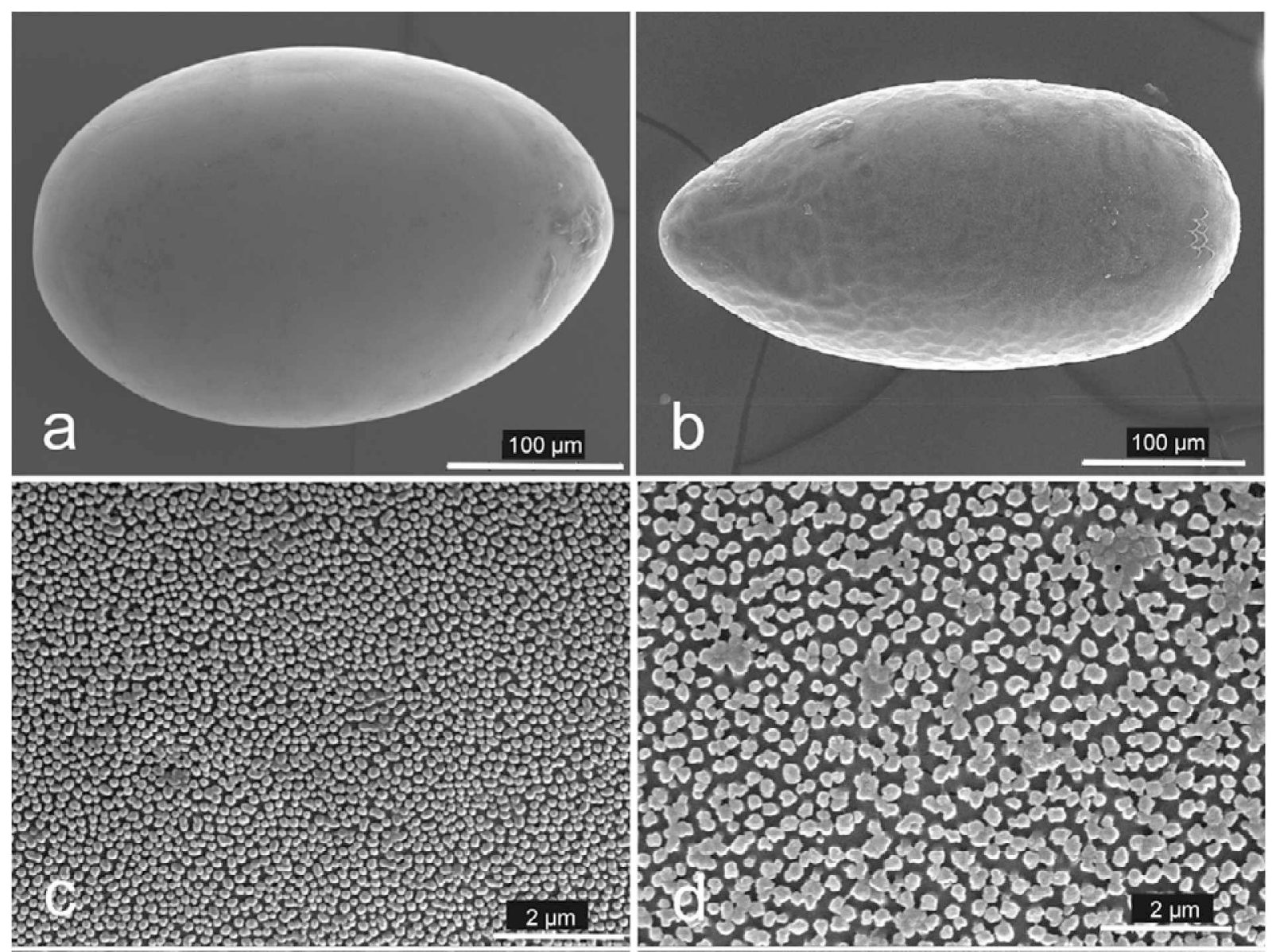

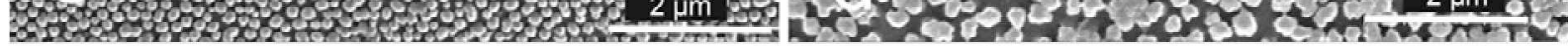
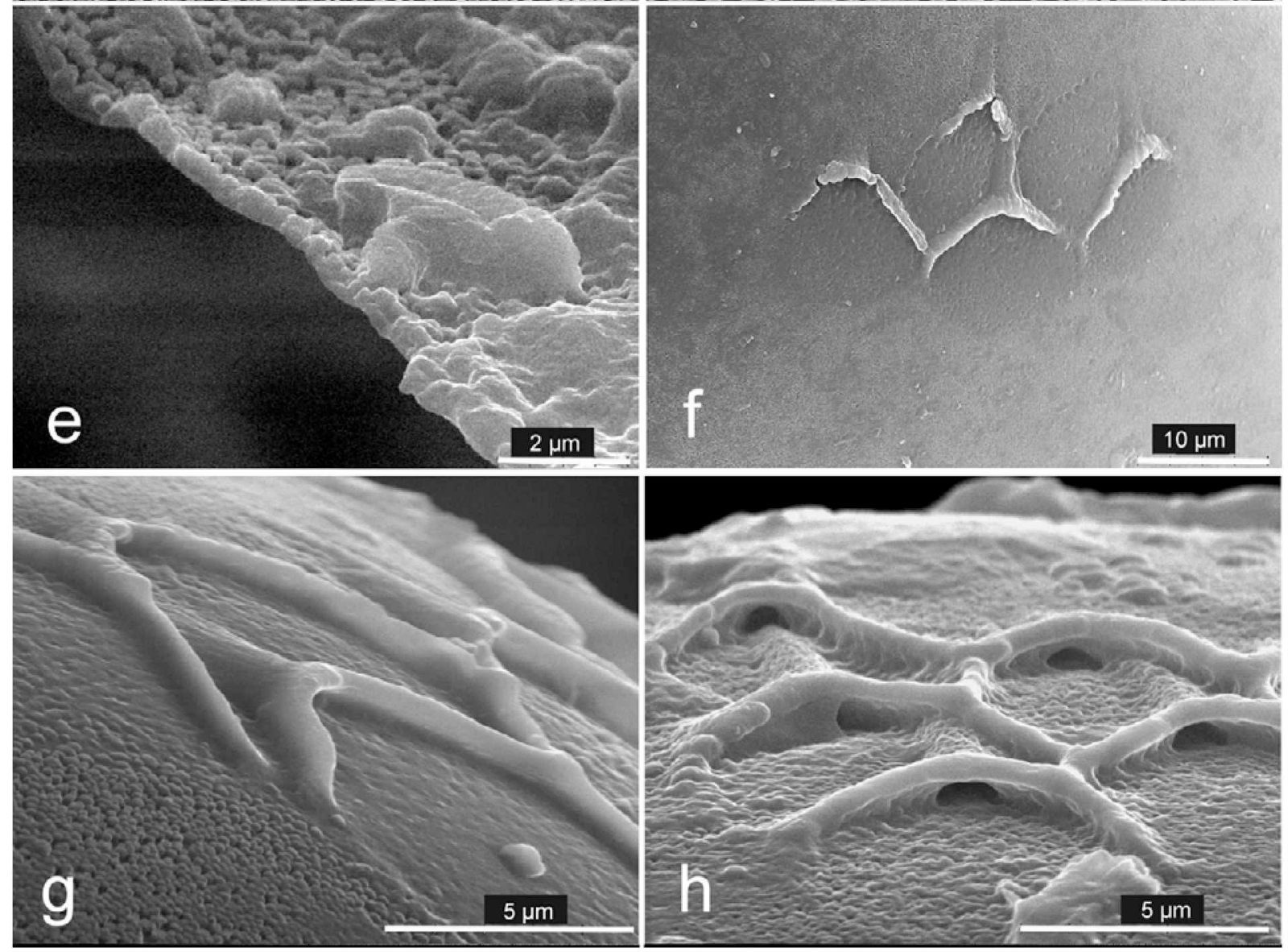
surfaces, bears half-globular tubercles (circular in crosssection, about $1.0-1.1 \mu \mathrm{m}$ in diameter and $0.5 \mu \mathrm{m}$ high) (Fig. $8 \mathrm{c}$ ). The shell on the undersurface of an egg (i.e. the dorsal surface, which is stuck to a seed or substratum) consist of only the inner layer, the outer layer being absent (Fig. 8b). The 2-3 micropyles (Fig. 8e,f) are situated at the boundary between the upper and lateral parts at the posterior end. The inner diameter of the opening is about $1.5-2.5 \mu \mathrm{m}$.

On the upper surface of an egg near the anterior end there is an area that lacks the outer layer (Fig. 8g). This area is mostly irregularly rounded, but varies in size and shape. It is either bare or bears some remnants of the outer layer. The structure of the outer layer is visible at the margins of this area. The outer surface of the chorion is connected to the inner layer by struts with airspaces between them (Fig. 8h). That is, there appears to be an airspace between the inner and outer layers of the chorion, and air enters this space via the special area at the anterior end of the egg.

\section{DISCUSSION}

\section{Sculpturing}

Eggs of higher psocids usually lack any conspicuous sculpturing. Those of more primitive psocids usually have pronounced areolate sculpturing, for example in the Lepidopsocidae, Sphaeropsocidae and Trogiidae, there are elaborate folds or ridges on the upper surface. These structures may be of considerable systematic value (New, 1987: p. 4). Ridges and pitting result from the uneven laying down of chorion by the follicle cells (Chapman, 1982).

In all the psocid genera studied here (suborders Trogiomorpha, Troctomorpha and Psocomorpha) different chorion macro- or microstructures of systematic value were found that enabled the identification of eggs or egg shells at both the generic and species level.

\section{Embryo position, hatching}

According to Seeger, 1979 (p. 37), the ventral side of a psocid embryo lies uppermost in an egg. During hatching the oviruptor on the front of an embryo cuts a slit in the anterior third of the egg and the nymph is partially extruded through this hole. This is the case for all psocid eggs studied here. The position of the embryo within an egg differs from that seen in other Paraneoptera, and is considered to be a synapomorphy of the order Psocoptera by Seeger (1979: p. 39)

\section{Thickness of the chorion}

In this study, cross-sections of eggs were not scrutinised. However, it was possible to measure chorion thickness from SEM micrographs of the edges of pieces of egg-shell. The chorion of Liposcelis, Trogium, Lepinotus, Dorypteryx and Psyllipsocus was found to be $<0.5 \mu \mathrm{m}$ thick, which corresponds with published results (Seeger, 1979). The egg of L. pedicularia is an exception. In this case the egg shell is about twice as thick as in the others genera. The reason is that the egg of $L$. pedicularia has an additional surface layer (extrachorion), which is separated by an airspace from the basal layer $(0.5 \mu \mathrm{m})$ found in all other psocids. This species belongs to the more advanced suborder Psocomorpha, whereas the other species are members of the suborders Trogiomorpha and Troctomorpha.

\section{Micropylar and respiratory area}

Insect eggs usually have a micropyle, which is a funnel-shaped opening passing through the chorion and permitting sperm to enter and fertilize an egg. An egg is normally oriented in an oviduct in such a way that the micropylar region is in the proximity of the site of sperm release (spermathecal duct) (Romoser, 1973; Gillott, 1980). Most insect eggs have only a single terminal micropyle, but some (e.g. Orthoptera: Acrididae, Heteroptera) have more then one micropyle (Chapman, 1982, 1991; Cobben, 1968). They are very often near to the anterior end (e.g. Lepidoptera: Arbogast et al., 1980; Heteroptera: Cobben, 1968), but can be located at various other places on an egg (Romoser, 1973; Crowson, 1981; Cobben, 1968). The size of a micropyle, (e.g. that of the eggs of Heteroptera, measured at its narrowest diameter) is about $1-3 \mu \mathrm{m}$.

On the other hand, psocid eggs were not thought to have a micropyle or aeropyle because the chorion of their eggs is thin (cf. Seeger, 1979). For the Psocoptera the extremely thin chorion and the absence of openings were considered to be derived characters (Seeger, 1979; Lienhard, 1998). However, special areas with two types of openings were observed in psocid eggs in this study. The function of these openings was not verified, but it is presumed that the regularly oval openings are micropyles. They are situated at the posterior end of an egg in all genera, vary in number (2-13) between and within species and have a diameter of $1.2-3 \mu \mathrm{m}$. This is consistent with the situation in other insect eggs. The diameter of the micropyle openings in L. inquilinus is similar to that of the spermathecal duct in Lepinotus $(1.5 \mu \mathrm{m})$ (WearingWilde, 1995). As mentioned above, Seeger (1979) did not observe micropyles in psocids, but he did find microstructures on the ventral surface of the chorion at the posterior end of the eggs of Prionoglaris stygia and described them as hooks (Seeger 1979: Fig. 1a: HF). The position and appearance of these structures is similar to that of the micropylar area, with the openings ressembling hooks when viewed under a light microscope.

It would be interesting to know why these supposed micropylar openings are present in parthenogenetic psocids (e.g. L. bostrychopila, L. reticulatus). As in other insect groups, parthenogenetic reproduction in the psocid

Fig. 7. a - Liposcelis paeta, entire egg (dorsal view, anterior end at right); $\mathrm{b}-$ L. brunnea, mature egg (upper = ventral view, anterior end at left); $\mathrm{c}-$ L. paeta, granulation (middle); $\mathrm{d}-$ L. corrodens, granulation (middle); e - L. decolor, egg shell after hatching; $\mathrm{f}$ - L. paeta, micropyles (posterior end); g - L. bostrychophila, micropylar area (lateral view, posterior end); $\mathrm{h}-L$. corrodens, micropyle openings. 


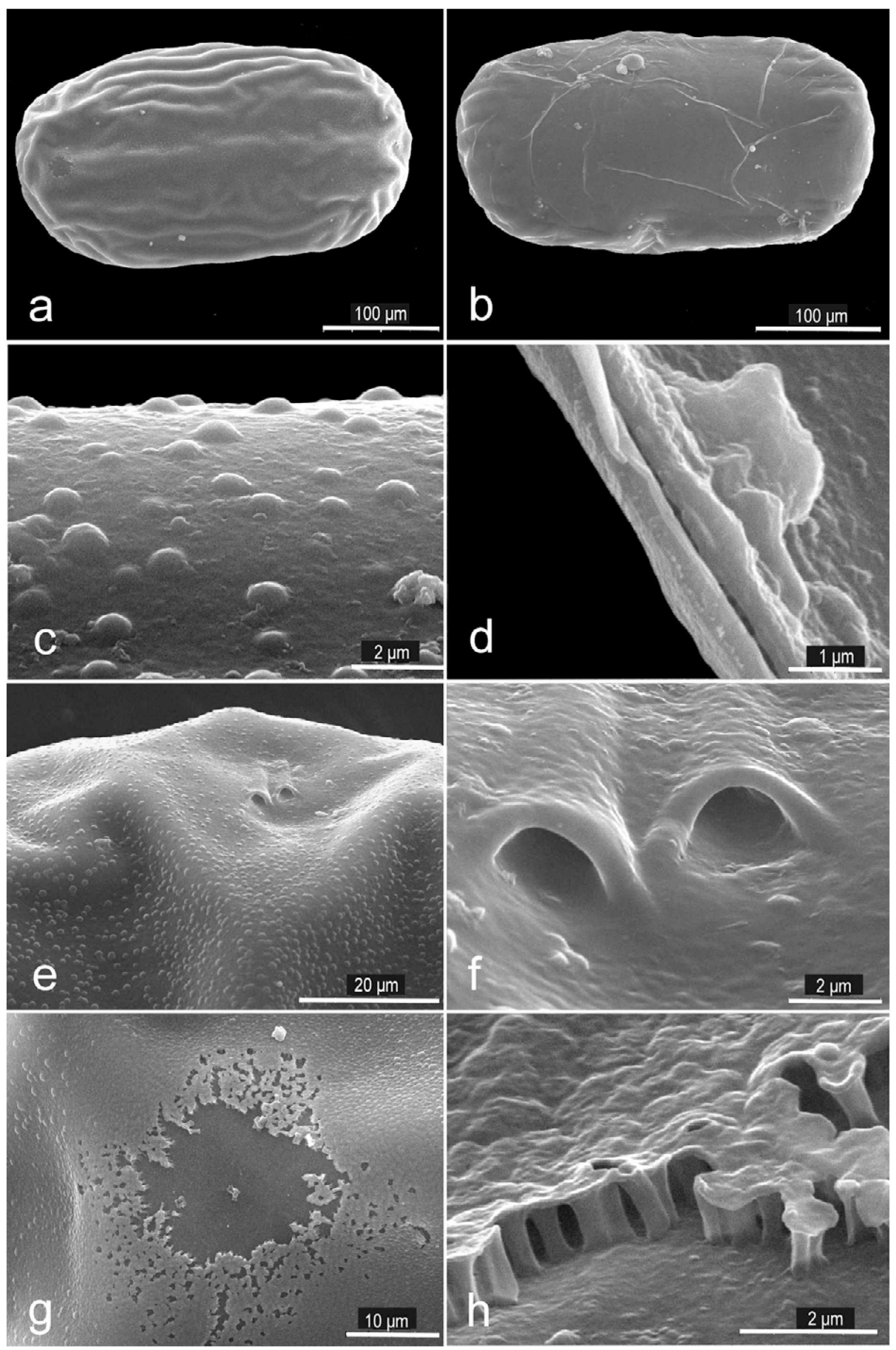


Fig. 8. Lachesilla pedicularia: $\mathrm{a}$ - entire egg (upper = ventral view, anterior end at left); $\mathrm{b}-$ entire egg (bottom $=\mathrm{dorsal}$ view, anterior end at left); $\mathrm{c}$ - bulge (anterior end); $\mathrm{d}$ - egg shell after hatching; e - micropyles (posterior end); $\mathrm{f}$ - detail of micropyle opening; $\mathrm{g}$ - bare area (anterior end); $\mathrm{h}$ - struts connecting outer to inner chorion (margin of the bare area).

L. bostrychophila is a result of an infection by the rickettsia Wolbachia (Yusuf et al., 2000). The functionless micropylar openings probably have yet to disappear during evolution, or they may have an other additional function, for example, in respiration, as proposed for some Heteroptera by Cobben (1968).

Absorption of oxygen and emission of carbon dioxide by insect eggs may occur over the entire surface when the chorion is thin or via aeropyles (Romoser, 1973; Crowson, 1981; Hinton, 1981). Aeropyles are usually scattered over the entire surface, or are restricted to a limited area. The openings are circular, elliptical, or may also be quite irregular, and often vary considerably in size and shape, even on a single egg (e.g. Lepidoptera: Arbogast et al., 1980). As was mentioned above, it is generally assumed in the literature that psocids lack aeropyles. The existence of stalked aeropyles in Rhyopsocus philipsae is the only published exception (Hinton, 1981). In this study no aeropyles were found in the genera Liposcelis, Dorypteryx and Psyllipsocus but the other two genera of Trogiomorpha, Trogium and Lepinotus, have openings that could have a respiratory function. They are narrower than micropyles, irregular in shape, and concentrated at the anterior end or at both ends of an egg. The chorions of the genera with and without these openings are surprisingly similar in thickness, i.e. very thin $(<0.5 \mu \mathrm{m})$. A special situation occurs in the eggs of Lachesilla pedicularia, where there are no visible openings, but the outer chorion layer encloses air spaces, which probably have a respiratory function. The inner chorion appears to consist of a continuous solid sheet. A similar situation is found in some Orthoptera (Chapman, 1982). The solid part of the egg shell may consist of a meshwork of chorionin fibrils, similarly to that observed in Rhodnius prolixus (Heteroptera, Hinton, 1962).

ACKNOWLEDGEMENTS. I would like to thank Jiřina Hromádková (IMCH ASCR) and M. Jokeš (RICP) for taking the SEM micrographs and C. Lienhard (Museum of Natural History, Geneva) and J. Zuska for critical reading of the manuscript and valuable suggestions. This research was supported by the Grant No. 522/99/1255 of the Grant Agency of the Czech Republic.

\section{REFERENCES}

Arbogast R.T., LeCato G.L. \& Van Byrd R. 1980: External morphology of some eggs of stored - product moths (Lepidoptera: Pyralidae, Gelechiidae, Tineidae). J. Insect Morphol. Embryol. 9: 165-177.

CHAPMAN R.F. 1982: The Insects Structure and Functions. 3th edition, Hodder \& Stoughton, London, 919 pp.

Chapman R.F. 1991: General anatomy and function. Chapter 2, 33-67. In: The Insect of Australia. Melbourne University Press, Second Edition, Vol.1, Carlton, 542 pp.

Cobben R.H. 1968: Evolutionary Trends in Heteroptera. Part I Eggs, architecture of the shell, gross embryology and eclosion. Centre for Agricultural Publishing \& Documentation, Wageningen, $475 \mathrm{pp}$.

Crowson R.A. 1981: The Biology of the Coleoptera. Academic Press, London, $802 \mathrm{pp}$.

Gilloti C. 1980: Entomology. Plenum Press, New York, 729 pp.

HINTON H.E. 1962: Entomology. Respiratory system of insect egg-shells. Science Progress, London, Vol. L, 197, pp. 96113.

Hinton H.E. 1981: Biology of Insect Eggs. Pergamon Press, Oxford, 3 vols., 999 pp.

KuČ́EROVÁ \& Z. JOKEŠ M. 2002: External morphology of eggs of the synanthropic psocid Dorypteryx domestica (Psocoptera: Psyllipsocidae). Dts. Entomol. Z. 49: 165-169.

Kučerová Z. \& Stejskal V. 2002: Comparative egg morphology of silvanid and laemophloeid beetles (Coleoptera) occurring in stored products. J. Stor. Prod. Res. 38: 219-227.

LienHARD C. 1998: Psocoptères Euro-Méditerranéens. - Faune de France, 83, Fédération Francaise des Sociétés de Sciences naturelles, Paris, $517 \mathrm{pp}$.

NEw T.R. 1987: Biology of the Psocoptera. Oriental Insects 21: $1-109$.

Romoser W.S. 1973: The Science of Entomology, Macmillan Publishing Co., New York, 449 pp.

SEEGER W. 1979: Spezialmerkmale an Eihüllen und Embryonen von Psocoptera im Vergleich zu anderen Paraneoptera (Insecta); Psocoptera als monophyletische Gruppe. Stuttgart. Beitr. Naturk. (Ser. A.), 329: 1-57.

WEARING-WILDE J. 1995: The sclerotized spermatophore of the barklouse Lepinotus patruelis. Tissue \& Cell 27: 447-456.

Yusuf M., Turner B., Whitfield P., Miles R. \& Pacey J. 2000: Electron microscopical evidence of a vertically transmitted Wolbachia-like parasite in the parthenogenetic, store-product pest Liposcelis bostrychophila Badonnel (Psocoptera). J. Stor. Prod. Res. 36: 169-175.

Received October 24, 2001; revised December 18, 2001; accepted February 8, 2002 